\title{
Preparation and Characterization of bis (4-methoxyanilinium) tetrachlorozincate
}

\author{
H.Rahmouni ${ }^{\mathrm{a}}$, W.Smirani Sta ${ }^{*, a}$, M.Rzaigui $^{\mathrm{a}}$
}

a-Laboratoire de chimie des matériaux, Faculté des sciences de Bizerte, 7021, Zarzouna, Tunisia

*Corresponding author: wajda_sta@yahoo.fr

\section{ABSTRACT}

A new zinc complex of formula $\left[\mathrm{C}_{7} \mathrm{H}_{10} \mathrm{NO}_{2} \mathrm{ZnCl}_{4}\right.$ has been prepared and characterized by $\mathrm{X}$-ray diffraction, IR and UV-Visible spectroscopies. The complex crystallizes in the monoclinic space group $\mathrm{P} 2{ }_{1} / \mathrm{n}$ with a minimal tetrahedral distortion of the $\mathrm{ZnCl}_{4}{ }^{2-}$ ion and with lattice parameters: $a=12.054$ (2) $\AA, b=7.129$ (3) $\AA, c=23.480$ (2) $\AA, \beta=100.67$ (2) , $V=1983.03(1) \AA^{3}$ and $Z=4$. The crystal structure was solved and refined to $R=0.080$ and $R_{w}=0.227$ with 9611 independent reflections. It can be described by organic layers of $\mathrm{p}$-anisidinium cations held together by $\mathrm{C}-\mathrm{H}$...O hydrogen bonds parallel to (010) plane, linked to the inorganic groups of $\mathrm{ZnCl}_{4}{ }^{2-}$ anions through $\mathrm{N}-\mathrm{H}$...Cl hydrogen bonds, electrostatic and Van Der Waals interactions, to form a three-dimensional network.

\section{Indexing terms/Keywords}

Organic-inorganic hybrid, Crystal structure, IR Spectroscopy.

\section{Council for Innovative Research}

Peer Review Research Publishing System

Journal: Journal of Advances in Chemistry

Vol. 10, No. 3

editorjaconline@gmail.com

www.cirjac.com 


\section{INTRODUCTION}

Organic-inorganic hybrid materials have gained enormous attention in recent years due to their interesting crystal structure and some special properties such as magnetic, optical, electrical and catalytic activity [1]. A recent advance in this field is to design the coordination frameworks of tetrahalometallates by the incorporation of various organic cations giving new structures with interesting applications [2]. Self-assembly process of such hybrid materials in solid state arises due to the variety of interactions including ionic interactions, hydrogen and halogen bondings and Van Der Waals interactions [3]. In the present investigation, we report the synthesis and crystal structure of a new organic-inorganic hybrid zinc complex, $\left[\mathrm{C}_{7} \mathrm{H}_{10} \mathrm{NO}_{2} \mathrm{ZnCl}_{4}\right.$. Characterization of this material by IR and UV-Visible spectroscopies is also reported.

\section{EXPERIMENTAL}

\subsection{Material Preparation}

The title compound was prepared in a Petri dish by slow evaporation of an ethanolic solution of 4-methoxyaniline (2 $\mathrm{mmol})$, zinc chloride $(1 \mathrm{mmol})$ and diluted hydrochloric acid $(10 \mathrm{~mL}, 1 \mathrm{M})$ at room temperature. The crystals remained stable under normal conditions of temperature and humidity. The chemical formula was determined by $\mathrm{X}$-ray crystal structure analysis.

\subsection{Physical measurement}

The unit -cell dimensions were refined using X-ray diffraction data collected with a Mach 3 Enraf Noninus diffractometor using $\mathrm{Ag} \mathrm{Ka}$ radiation. Crystal data, parameters used for diffraction data collection and strategy used for the crystal structure determination and their results, are listed in Table 1. The atomic coordinates and equivalent isotropic displacements are shown in Table 2.

IR spectra were recorded using $\mathrm{KBr}$ pellets in the range of $4000-400 \mathrm{~cm}^{-1}$ on a Nicolet IR200 FT-IR Spectrometer at ambient temperature.

Electronic spectra absorptions were made on a Perkin-Elmer Lambda UV-Visible spectrophotometer for $2.10^{-3} \mathrm{M}$ solution of $\left[\mathrm{C}_{7} \mathrm{H}_{10} \mathrm{NO}_{2} \mathrm{ZnCl}_{4}\right.$ in absolute ethanol solvent.

\section{RESULTS AND DISCUSSION}

\subsection{X-ray diffraction analysis}

The asymmetric unit of the title compound (Fig.1) contains two p-anisidinium cations and one tetrachlorozincate anion.

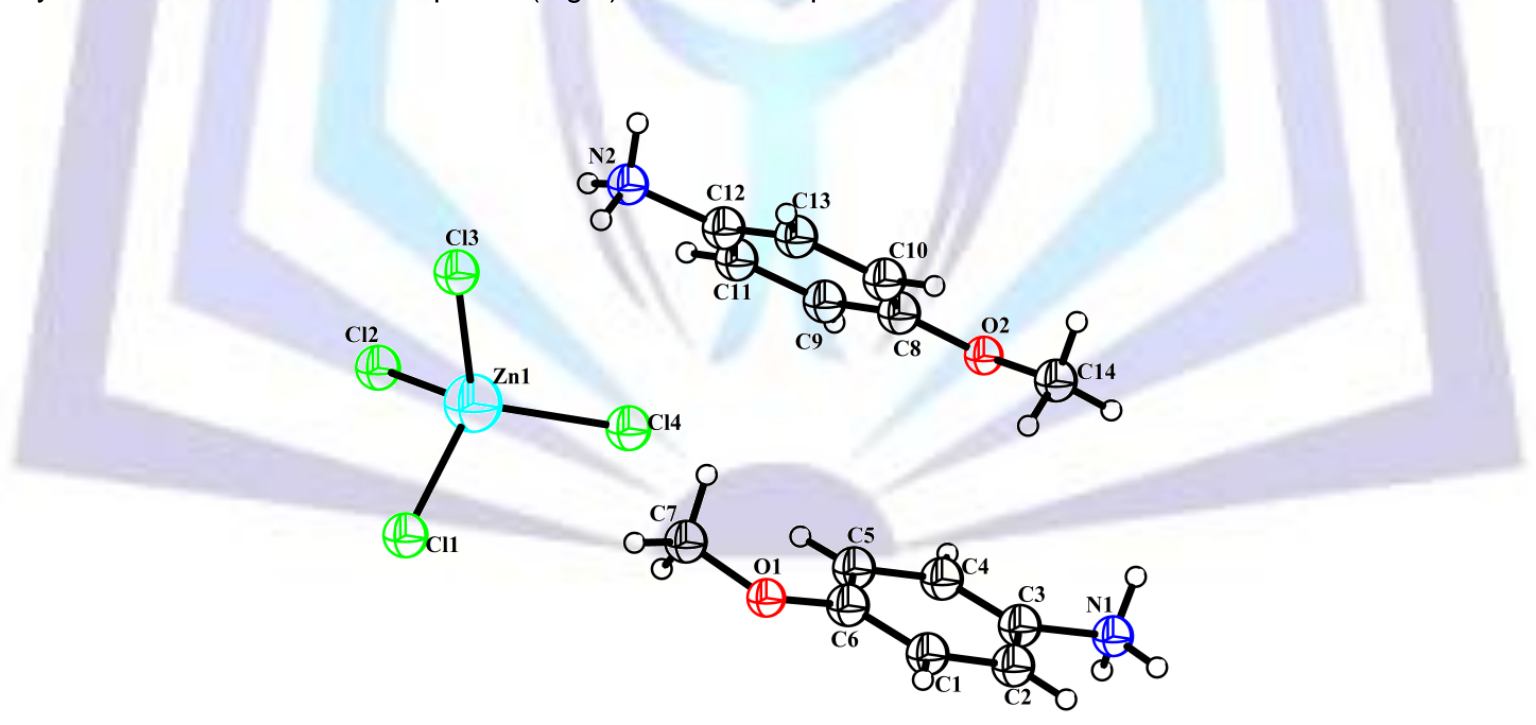

Figure 1. ORTEP view of $\left[\mathrm{C}_{7} \mathrm{H}_{10} \mathrm{NO}_{2} \mathrm{ZnCl}_{4}\right.$, showing $50 \%$ probability ellipsoids

The crystal structure consists of organic layers of $p$-anisidinium cations, parallel to the $(b, c)$ plane, held together by $\mathrm{C}$ $\mathrm{H}$... O hydrogen bonds. These layers are attached to the inorganic groups of $\mathrm{ZnCl}_{4}{ }^{2-}$ anions through $\mathrm{N}-\mathrm{H} \ldots \mathrm{Cl}$ hydrogen bonds, electrostatic and Van Der Waals interactions, to form a three-dimensional infinite network (Fig.2). 
Table 1. Crystal data and structure refinement

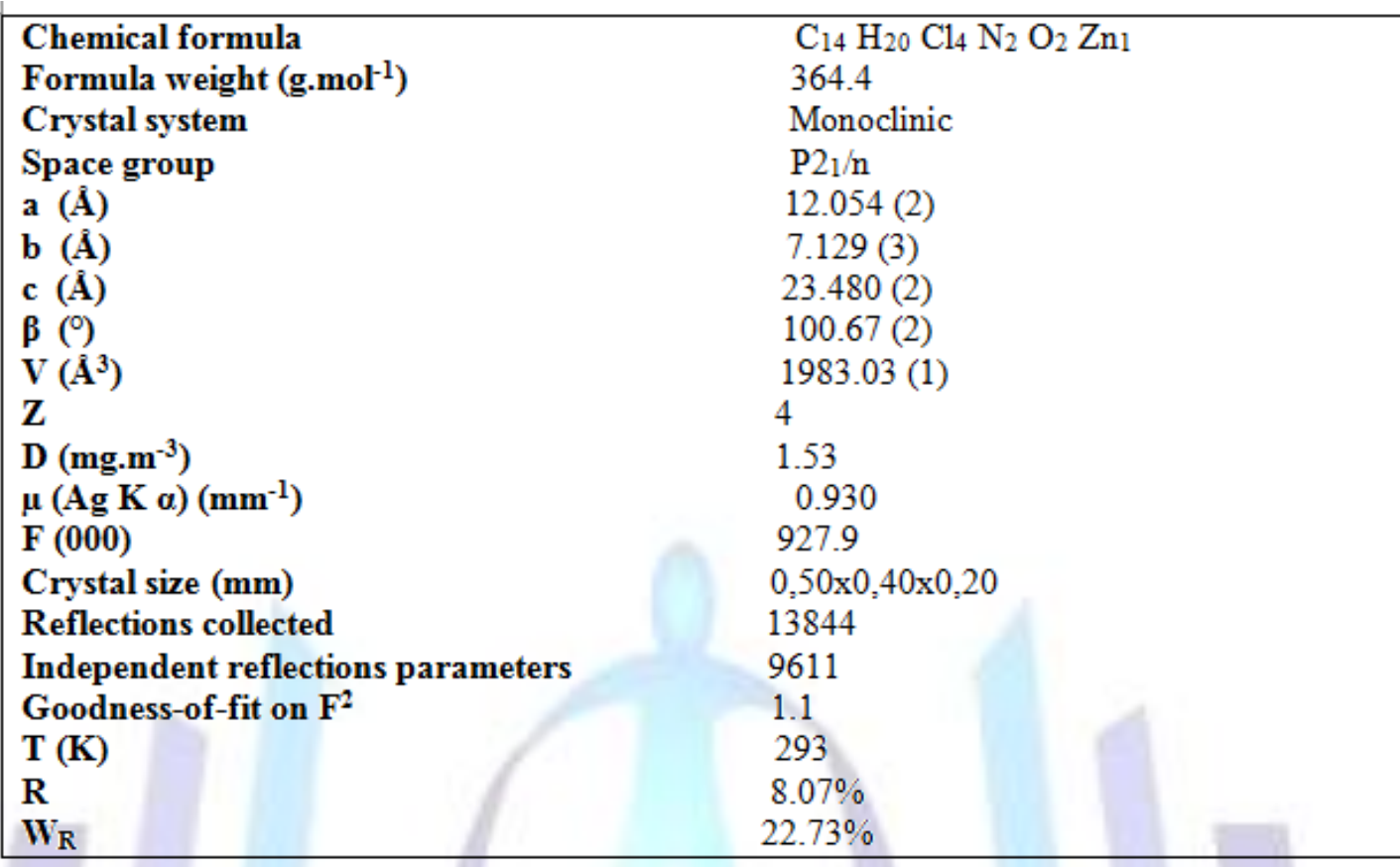

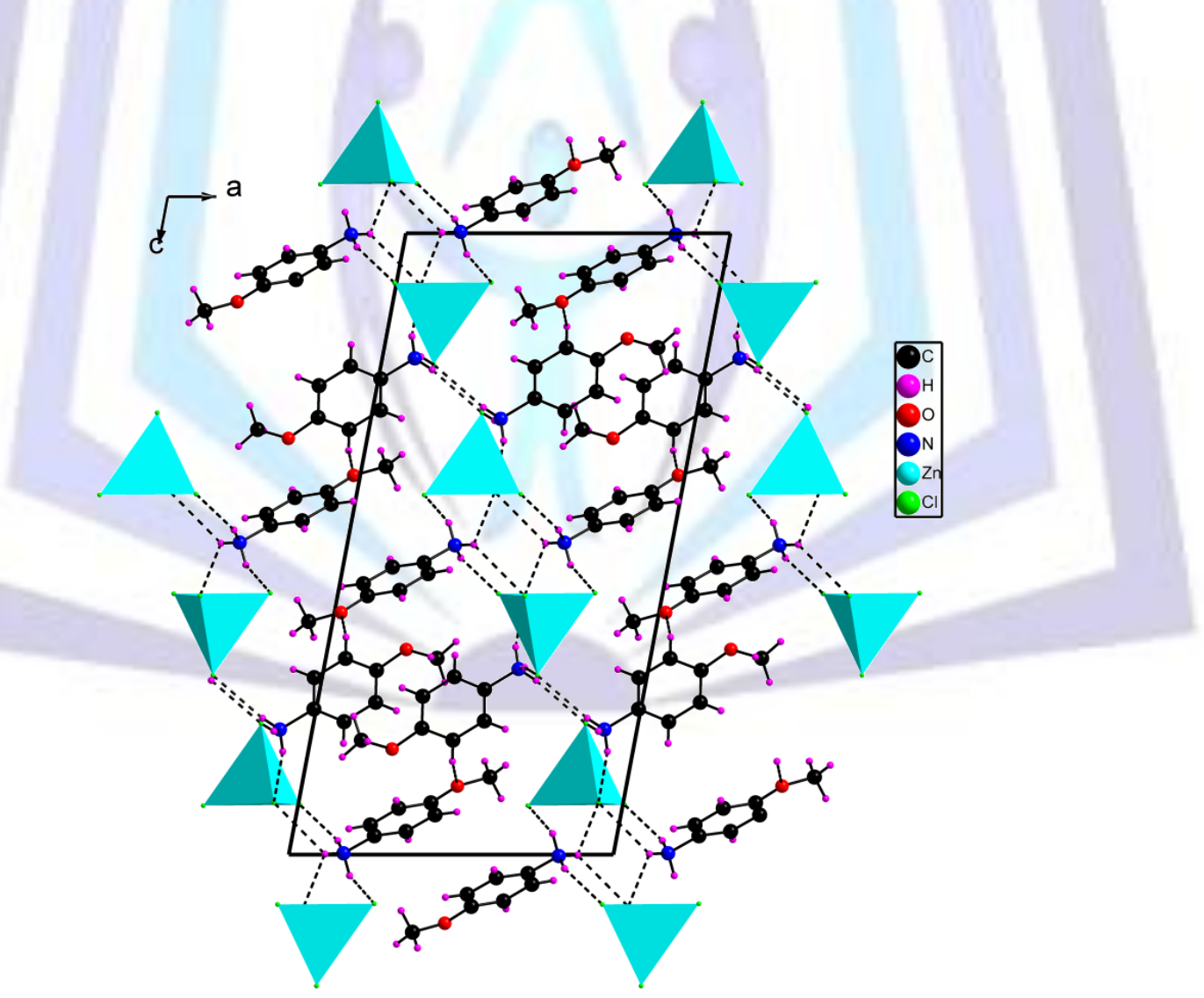

Figure 2. Projection of the structure of $\left[\mathrm{C}_{7} \mathrm{H}_{10} \mathrm{NO}_{2} \mathrm{ZnCl}_{4}\right.$ along the $b$ axis 
Table 2. Fractional atomic coordinates and equivalent isotropic displacements for $\left[\mathrm{C}_{7} \mathrm{H}_{10} \mathrm{NO}_{2} \mathrm{ZnCl}_{4}\right.$

\begin{tabular}{|c|c|c|c|c|}
\hline Atoms & $\mathbf{X}$ & $\mathbf{Y}$ & $\mathbf{Z}$ & $U_{\text {eq }} / U_{\text {iso }}$ \\
\hline $\mathrm{Cl} 1$ & $0.0762(1)$ & $0.5663(2)$ & $0.0837(5)$ & $0.0517(3)$ \\
\hline $\mathrm{Cl} 2$ & $-0.0056(1)$ & $1.0619(2)$ & $0.0801(5)$ & $0.0443(3)$ \\
\hline $\mathrm{Cl} 3$ & $0.1617(1)$ & $0.8648(2)$ & $0.2112(5)$ & $0.0568(3)$ \\
\hline $\mathrm{Cl} 4$ & $0.2918(1)$ & $0.9449(2)$ & $0.0790(5)$ & $0.0573(3)$ \\
\hline N1 & $0.8322(3)$ & $0.7334(6)$ & $0.0022(2)$ & $0.0479(1)$ \\
\hline C1 & $0.6884(4)$ & $0.3684(8)$ & $0.0746(3)$ & $0.0595(1)$ \\
\hline C3 & $0.7475(4)$ & $0.6378(6)$ & $0.0302(2)$ & $0.0411(1)$ \\
\hline C4 & $0.6525(4)$ & $0.7314(7)$ & $0.0373(2)$ & $0.0476(1)$ \\
\hline $\mathrm{C} 2$ & $0.7659(4)$ & $0.4548(7)$ & $0.0478(2)$ & $0.0540(1)$ \\
\hline $\mathrm{C} 5$ & $0.5726(4)$ & $0.6429(7)$ & $0.0640(2)$ & $0.0502(1)$ \\
\hline C6 & $0.5921(4)$ & $0.4608(7)$ & $0.0834(2)$ & $0.0517(1)$ \\
\hline O1 & $0.5203(4)$ & $0.3626(6)$ & $0.1104(2)$ & $0.0769(1)$ \\
\hline C9 & $0.5609(4)$ & $0.9609(7)$ & $0.1843(2)$ & $0.0462(1)$ \\
\hline $\mathrm{C} 7$ & 0.4258 & $0.4544(1)$ & $0.1248(3)$ & $0.0830(2)$ \\
\hline C8 & $0.6632(4)$ & $0.8724(6)$ & $0.2034(2)$ & $0.0394(1)$ \\
\hline $\mathrm{O} 2$ & $0.7430(3)$ & $0.8929(5)$ & $0.1698(1)$ & $0.0504(8)$ \\
\hline N2 & $0.3998(3)$ & $0.8294(6)$ & $0.2987(2)$ & $0.0468(9)$ \\
\hline C10 & $0.6791(4)$ & $0.7730(7)$ & $0.2549(2)$ & $0.0509(1)$ \\
\hline $\mathrm{C} 13$ & $0.5932(4)$ & $0.7612(7)$ & $0.2861(2)$ & $0.0513(1)$ \\
\hline C11 & $0.4753(4)$ & $0.9479(7)$ & $0.2151(2)$ & $0.0462(1)$ \\
\hline C14 & $0.8427(4)$ & $0.7823(9)$ & $0.1841(3)$ & $0.0708(2)$ \\
\hline $\mathrm{C} 12$ & $0.4928(3)$ & $0.8466(6)$ & $0.2657(2)$ & $0.0381(9)$ \\
\hline $\mathrm{Zn} 1$ & $0.1374(4)$ & $0.8585(7)$ & $0.1122(2)$ & $0.0397(2)$ \\
\hline $\mathrm{H} 1 \mathrm{~A}$ & 0.8897 & 0.6561 & 0.0010 & \\
\hline $\mathrm{H} 1 \mathrm{~B}$ & 0.8573 & 0.8354 & 0.0224 & \\
\hline $\mathrm{H} 1 \mathrm{~A}$ & 0.8897 & 0.6561 & 0.0010 & \\
\hline $\mathrm{H} 1$ & 0.7006 & 0.2452 & 0.0873 & \\
\hline $\mathrm{H} 2$ & 0.8289 & 0.3910 & 0.0416 & \\
\hline $\mathrm{H} 2 \mathrm{~A}$ & 0.3398 & 0.8921 & 0.2804 & \\
\hline $\mathrm{H} 2 \mathrm{~B}$ & 0.4218 & 0.8767 & 0.3341 & \\
\hline $\mathrm{H} 2 \mathrm{C}$ & 0.3820 & 0.7090 & 0.3014 & \\
\hline $\mathrm{H} 4$ & 0.6409 & 0.8543 & 0.0243 & \\
\hline H5 & 0.5071 & 0.7054 & 0.0686 & \\
\hline $\mathrm{H} 7 \mathrm{~A}$ & 0.3839 & 0.3678 & 0.1440 & \\
\hline H7B & 0.3785 & 0.5001 & 0.0902 & \\
\hline $\mathrm{H} 7 \mathrm{C}$ & 0.4506 & 0.5578 & 0.1502 & \\
\hline H9 & 0.5502 & 1.0299 & 0.1501 & \\
\hline $\mathrm{H} 10$ & 0.7477 & 0.7140 & 0.2684 & \\
\hline $\mathrm{H} 11$ & 0.4064 & 1.0067 & 0.2020 & \\
\hline $\mathrm{H} 13$ & 0.6038 & 0.6952 & 0.3208 & \\
\hline
\end{tabular}




\begin{tabular}{|c|c|c|c|}
\hline $\mathrm{H} 14 \mathrm{~A}$ & 0.8917 & 0.8083 & 0.1571 \\
\hline $\mathrm{H} 14 \mathrm{~B}$ & 0.8228 & 0.6518 & 0.1821 \\
\hline $\mathrm{H} 14 \mathrm{C}$ & 0.8808 & 0.8123 & 0.2226 \\
\hline
\end{tabular}

As shown in Fig.3, in the crystal structure of the title complex, $\mathrm{ZnCl}_{4}{ }^{2-}$ groups are connected by hydrogen bonds $\mathrm{N}-\mathrm{H}$...Cl. The organic and inorganic species interact by mean of seven $\mathrm{N}-\mathrm{H}$...Cl hydrogen bonds (Table 3 ), giving rise to a porous layer. The corresponding $\mathrm{N}$...Cl distances vary between $3.173(4)$ and $3.413(4) \AA$, which can be considered relatively weak [4]. In the organic layer, there are no $\pi-\pi$ interactions between the 4-methoxyanilinium cations, between which there is a face-to-face distance of $4 \AA$ which is longer than values observed in similar compounds [5].

Table 3. Hydrogen-bond parameters $\left(\AA{ }^{\circ}\right)$ for $\left[\mathrm{C}_{7} \mathrm{H}_{10} \mathrm{NO}_{2} \mathrm{ZnCl}_{4}\right.$

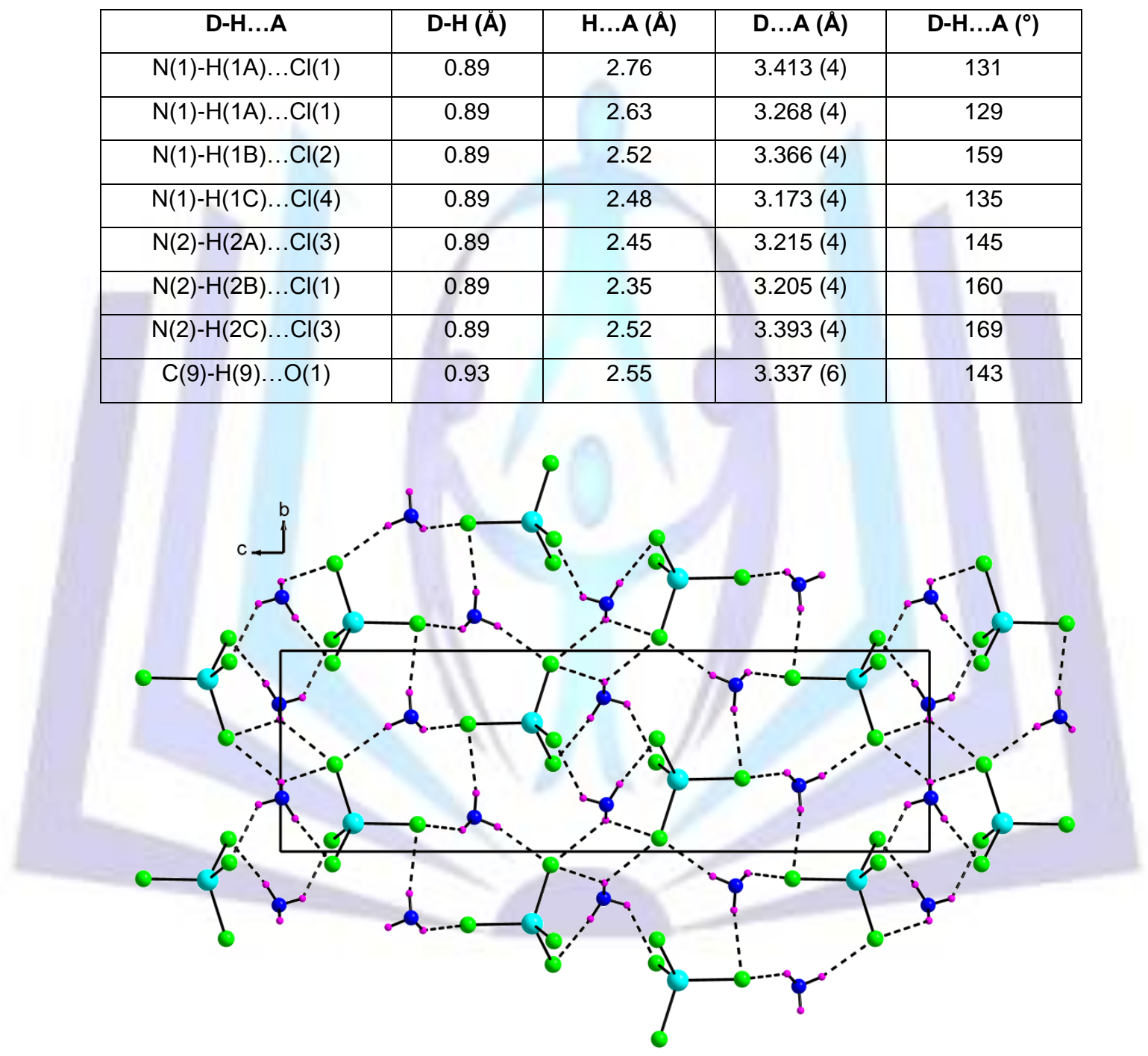

Figure 3. Projection of a layer of the structure of $\left[\mathrm{C}_{7} \mathrm{H}_{10} \mathrm{NO}_{2} \mathrm{ZnCl}_{4}\right.$ along the a direction

The zinc atom is tetrahedrally coordinated by chlorine atoms, with $\mathrm{Zn}-\mathrm{Cl}$ distances ranging from 2.234(1) to $2.288(1) \AA$ and $\mathrm{Cl}-\mathrm{Zn}-\mathrm{Cl}$ angles varying from 105.76(5) to $113.32(5)^{\circ}$ (Table 4). These values show a slight distortion of the $\mathrm{ZnCl}_{4}{ }^{2-}$ tetrahedra, which can be explained by the involving of the chlorine ions in the hydrogen bonding. These results are in agreement with those found in anilinium tetrachlorozincate [6]. The organic molecule exhibits a regular spatial configuration with normal distances $\mathrm{C}-\mathrm{C}, \mathrm{C}-\mathrm{N}$ and angles $\mathrm{C}-\mathrm{C}-\mathrm{C}, \mathrm{C}-\mathrm{C}-\mathrm{N}$ (Table 5). The mean value of the C-C length of the $\mathrm{C}_{6}$-ring is $1.4038 \AA$, which is between single and double bonds and agrees with that observed in the $\mathrm{C}_{6}$-ring of benzene derivatives [7]. All the carbon atoms of the C6-ring are coplanar and they form conjugated planes with average deviation of $\pm 0.042 \AA$ and $\pm 0.079 \AA$, and they form between them a dihedral angle of $7.45^{\circ}$. 
Table 4. Main interatomic distances ( $(\AA)$ and bond angles (deg) for $\mathrm{ZnCl}_{4}{ }^{2-}$

\begin{tabular}{|lllll|}
\hline $\mathrm{Zn}$ & $\mathrm{Cl1}$ & $\mathrm{Cl} 2$ & $\mathrm{Cl3}$ & $\mathrm{Cl}$ \\
$\mathrm{Cl} 1$ & $\mathbf{2 . 2 6 9 ( 1 )}$ & $3.665(1)$ & $3.662(1)$ & $3.762(1)$ \\
$\mathrm{Cl} 2$ & $107.63(5)$ & $\mathbf{2 . 2 7 2 ( 1 )}$ & $3.636(1)$ & $3.685(1)$ \\
$\mathrm{Cl} 3$ & $106.96(5)$ & $105.76(5)$ & $\mathbf{2 . 2 8 8 ( 1 )}$ & $3.772(1)$ \\
$\mathrm{Cl} 4$ & $113.33(5)$ & $109.72(5)$ & $113.04(5)$ & $\mathbf{2 . 2 3 4}(\mathbf{1})$ \\
\hline
\end{tabular}

Table 5. Main interatomic distances $(\AA \AA)$ and bond angles $\left(^{\circ}\right)$ for organic groups

\section{4- $\left(\mathrm{OCH}_{3}\right) \mathrm{C}_{6} \mathrm{H}_{4} \mathrm{~N}(1) \mathrm{H}_{3}{ }^{+}$}

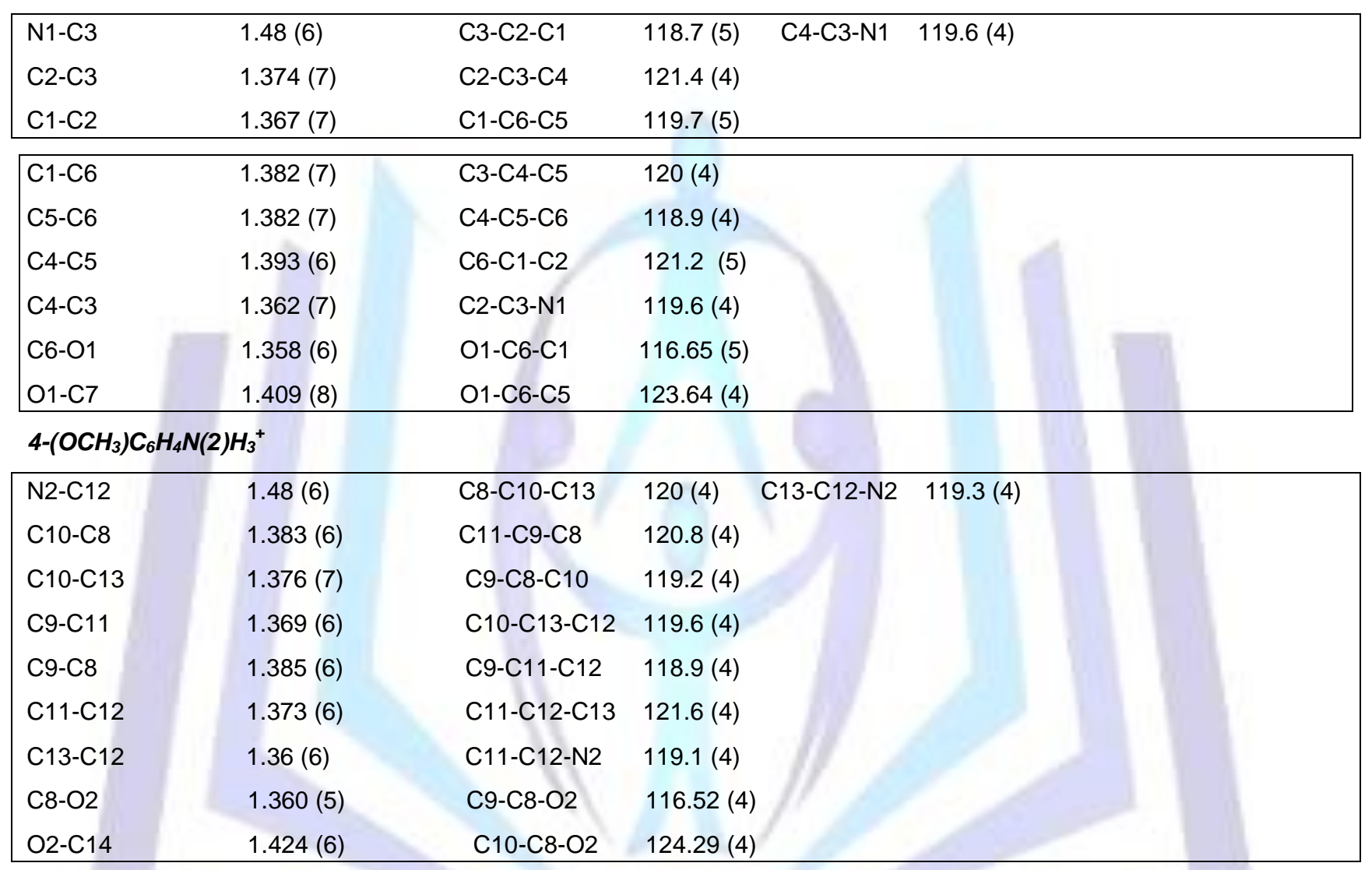

Furthermore, the distances of $\mathrm{C}(7)-\mathrm{O}(1), \mathrm{C}(14)-\mathrm{O}(2), \mathrm{C}(3)-\mathrm{N}(1)$ and $\mathrm{C}(12)-\mathrm{N}(2)[1.409$ (7) $\AA$, 1.424 (6) $\AA$, $1.480(6) \AA$, $1.481 \AA$ ] indicate two single bonds in each cation.

However, the $\mathrm{C}(6)-\mathrm{O}(1)$ and $\mathrm{C}(8)-\mathrm{O}(2)$ distances [1.358(3) $\AA$ and $1.360(1) \AA]$ are shorter which is probably due to the mesomeric effect of the methoxy groups [8].

The coplanar methoxy groups are characterized by the torsion angles $\mathrm{C}(1)-\mathrm{C}(6)-\mathrm{O}(1)-\mathrm{C}(7)$ and $\mathrm{C}(9)-\mathrm{C}(8)-\mathrm{O}(2)-\mathrm{C}(14)$ being $174.6^{\circ}$ and $-171.3^{\circ}$ respectively.

The $O(1)-C(6)-C(5)$ and $O(2)-C(8)-C(10)$ angles [123.64 and $124.29^{\circ}$ ] are larger than the $O(1)-C(6)-C(1)$ and $O(2)-C(8)$ $\mathrm{C}(9)$ angles $\left[116.65^{\circ}\right.$ and $\left.116.52^{\circ}\right]$. This can be attributed to the establishment of weak C-H...O intramolecular hydrogen bonds [8].

\subsection{Infrared Spectroscopy}

The IR vibrational frequencies of the free 4-methoxyaniline have been taken for band assignments and to verify the shift in their frequencies with the present compound [9-10].

The IR spectrum (Fig. 4) of $\left[\mathrm{C}_{7} \mathrm{H}_{10} \mathrm{NO}_{2} \mathrm{ZnCl}_{4}\right.$ shows absorption bands in the region $3500-2800 \mathrm{~cm}^{-1}$ due to the $\mathrm{N}-\mathrm{H}$ and $\mathrm{C}-\mathrm{H}$ antisymmetric and symmetric stretching modes respectively of $-\mathrm{NH}_{3}{ }^{+}$and $-\mathrm{CH}_{3}$ groups. These bands are shifted to lower wave number in the spectrum of $\left[\mathrm{C}_{7} \mathrm{H}_{10} \mathrm{NO}_{2} \mathrm{ZnCl}_{4}\right.$ which is due to the formation of hydrogen bonds $\mathrm{N}-\mathrm{H} \ldots \mathrm{Cl}$.

Bending vibrations of $-\mathrm{NH}_{3}{ }^{+}$and $-\mathrm{CH}_{3}$ groups appear in the region $1650-1400 \mathrm{~cm}^{-1}$. The vibrations observed in the domain $1400-1000 \mathrm{~cm}^{-1}$ can be assigned to aromatic C-N stretches. The bands situated between $1000-650 \mathrm{~cm}^{-1}$ are due to aromatic $\mathrm{C}-\mathrm{H}, \mathrm{C}-\mathrm{C}$ and $\mathrm{C}-\mathrm{N}$ out of plane deformations. 


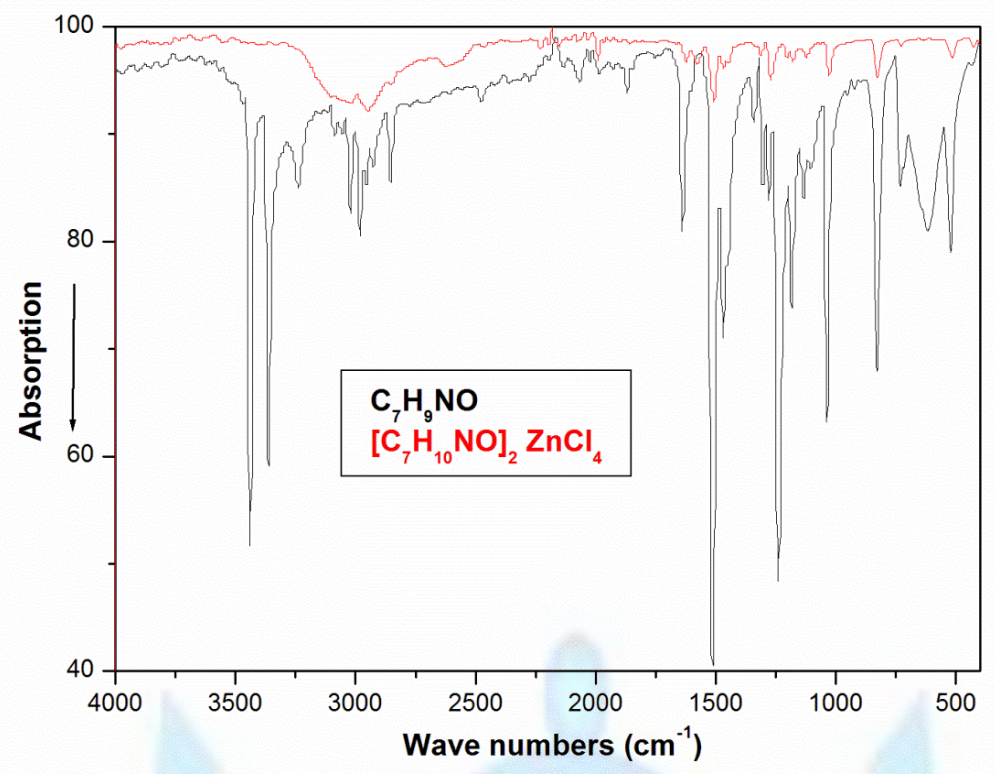

Figure 4. IR absorption spectrum of $\left[\mathrm{C}_{7} \mathrm{H}_{10} \mathrm{NO}_{2} \mathrm{ZnCl}_{4}\right.$

\subsection{UV Absorption and Diffuse Reflectance}

The optical absorption spectrum of $\left[\mathrm{C}_{7} \mathrm{H}_{10} \mathrm{NO}_{2} \mathrm{ZnCl}_{4}\right.$ was measured in the range $200-800 \mathrm{~nm}$ and the spectrum is shown in Fig.5.

In figure 5, we observe two strong absorption bands at 276 and $282 \mathrm{~nm}$ due to the $\pi \rightarrow \pi^{*}$ transitions. The spectrum shows also a broad weak band around $306 \mathrm{~nm}$ which can be attributed to the $\mathrm{n} \rightarrow \pi^{*}$ transition.

As the direct band gap $\left[\mathrm{C}_{7} \mathrm{H}_{10} \mathrm{NO}_{2} \mathrm{ZnCl}_{4}\right.$ has an absorption coefficient ( $\alpha$ ) obeying the relation for high photon energies (hv):

$\alpha=\frac{A(h v-E g)^{1 / 2}}{h w}$

where $\mathrm{Eg}$ is the band gap energy of the crystal and $\mathrm{A}$ is a constant.

The plot of variation of $(\alpha h v)^{2}$ vs.hv is shown in Fig.6. The band gap energy is found to be $4.26 \mathrm{eV}$. This value suggests that the studied compound could be used for optical applications in far UV region [12] as well as for dielectric properties [13].

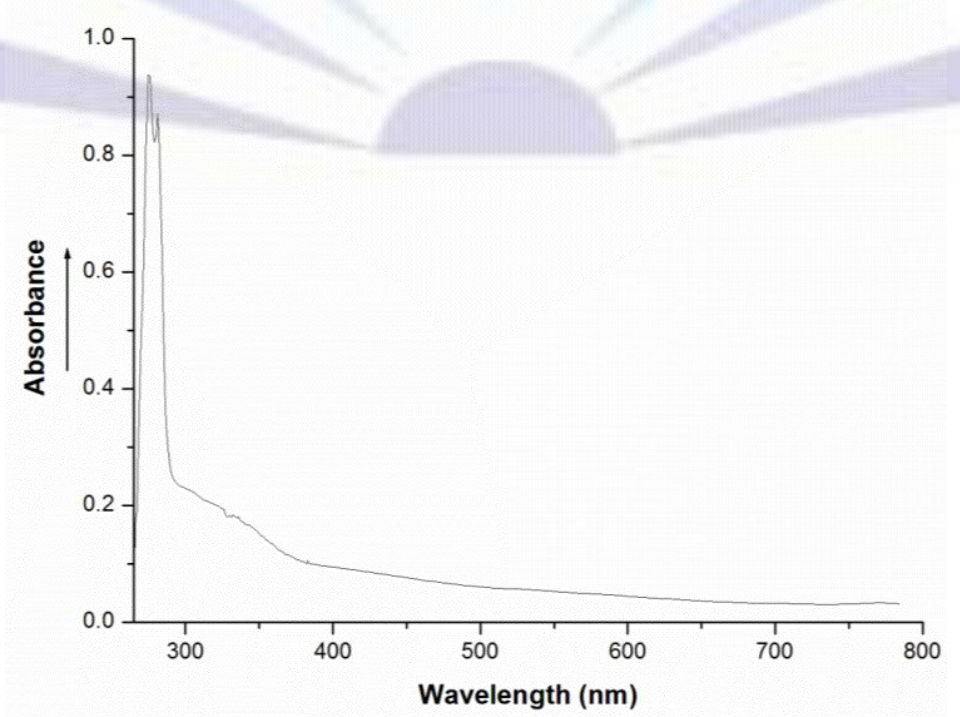

Figure 5. UV Absorption spectrum of $\left[\mathrm{C}_{7} \mathrm{H}_{10} \mathrm{NO}_{2} \mathrm{ZnCl}_{4}\right.$ 


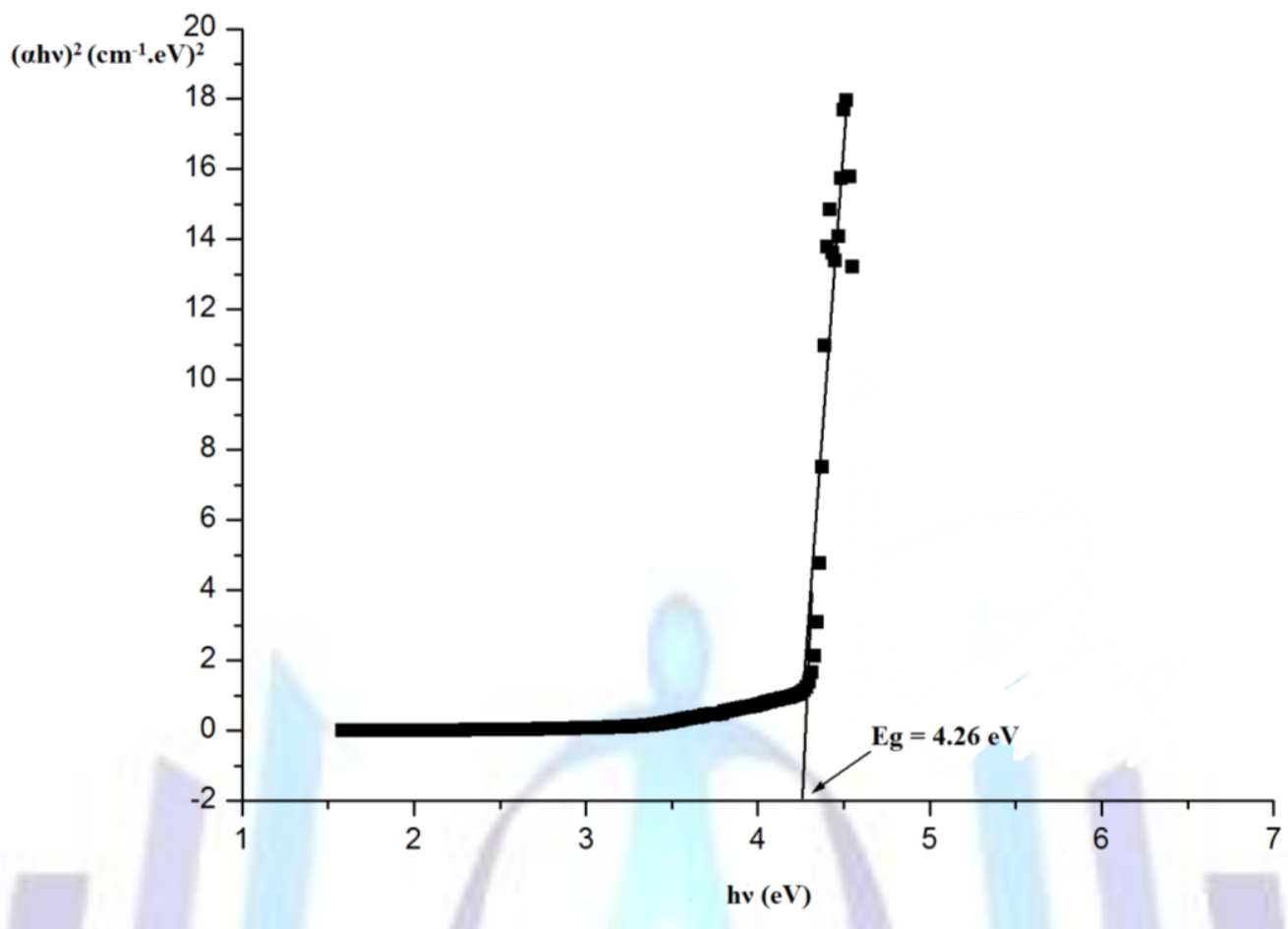

Figure 6. Plot of $(\alpha h v)^{2}$ vs.hv

\subsection{Conclusion}

A new hybrid material, $\left[\mathrm{C}_{7} \mathrm{H}_{10} \mathrm{NO}_{2} \mathrm{ZnCl}_{4}\right.$, has been prepared. Its atomic arrangement is described by organic layers of 4-methoxyanilinium cations attached to the inorganic groups of $\mathrm{ZnCl}_{4}{ }^{2-}$ anions through $\mathrm{N}-\mathrm{H} \ldots \mathrm{Cl}$ hydrogen bonds as to form a three-dimensional network. The UV-Vis spectral analyses reveal that the crystal can be used as dielectric with a band gap energy of $4.26 \mathrm{eV}$.

\section{REFERENCES}

[1] S.A.Forsyth, U.Frohlich, P.Goodrich, H.Q.N. Gunaratne, C.Hardacre., A.Mckeown, K.R.Seddon, New J.Chem. 34 (2010) 723-731

[2] F.Neve, A.Crispini, O.Francescangeli, Inorg.Chem. 39 (2000) 1187-1194

[3] B.K.Saha, A.Nangia, M.Jaskolsk, Cryst Eng Comm. 7 (2005) 355-358

[4] I.D Brown, Acta Crystallogr.A32 (1976) 24

[5] Z.M.Jin, N.Shun, Y.-P.Lu, M.-L.Hu, L.Shen, Acta Crystallogr.C61 (2005) m43.

[6] Ning.G, Jianglong.,Yuan.C, Shijun.L and Zhiyoung.F, Acta Cryst.2007, E63, m2571

[7] Guo N, Yi.J, Chem Y, Liao Sand, Fu Z.Acta Cryst 2007; E63: m2571

[8] M.El Glaoui, R.Kefi, E.Jeanneau, F.Lefebvre and C.Ben Nasr, The open crystallography J, (2009), 2, 1-5

[9] K.Nakamoto, IR and Ra Spectra of Inorganic and Coordinating Compounds, Wiley Interscience, 1986.

[10] A.Chtioui, T.Guerfel, L.Benhamada, A.Jouini, J.Solid State Sci.3 (2001) 859.

[11] J.Mroz, R.Jakubas, Ferroelectr.Lett. (11) (1990) 53

[12] K.P.Bhuvana, S.R.Jebas, N.Gopalakrishnan, T.Balasubramanian, Mater.Lett.61 (2007) 4246.

[13] Khandpekar, M. M.; Pati, S. P. Solid. State. Sci. 12 (2010), 1831-1836. 